\title{
PENCEMARAN LINGKUNGAN PADA TUNGKU PEMBUATAN BRIKET KOKAS DAN PENGECORAN LOGAM SERTA PENCEMARAN LOGAM BERAT DI SENTRA INDUSTRI KECIL
}

\author{
Hasnedi \\ Pusat Teknologi Pengembangan Sumberdaya Energi \\ BPPT Gedung II Lt $20 \mathrm{JI}$. MH Thamrin 8 Jakarta 10340 \\ E-mail: hasnedi_2002@yahoo.com
}

\begin{abstract}
The coke production process by baking semi-coke briquette in a coke's baking oven will produce flue gas and smoke. The same also happens in its utilization test in metal foundry kiln known as "tungkik" (plunging) smelting kiln. The gas and smoke predictably contain heavy metals and polluted chemical compounds that will pollute the environment and disturbing the health of workers if their concentrations pass over defined standard quality level. The objective of this study is to examine the amount of heavy metals and chemical compound pollutants produced in the process of baking semi-coke to produce coke and in the utilization of coke as fuel in tungkik kilns. Measurement results show that heavy metals in the kiln's chimneys and chambers such as $\mathrm{As}, \mathrm{Cd}, \mathrm{Pb}$, and $\mathrm{Hg}$ could not actually be detected, while $\mathrm{Fe}, \mathrm{Na}, \mathrm{Al}$, $\mathrm{Ca}$, and $\mathrm{K}$ could be easily detected. The concentrations of such metals are in the range of: $\mathrm{Na}=100-315$ $\mu \mathrm{g} / \mathrm{m}^{3}, A l=215-360 \mu \mathrm{g} / \mathrm{m}^{3}, \mathrm{Ca}=786-1330 \mu \mathrm{g} / \mathrm{m}^{3}, \mathrm{Fe}=478-2300 \mu \mathrm{g} / \mathrm{m}^{3}$, and $\mathrm{K}=$ $0.25-0.5 \mu \mathrm{g} / \mathrm{m}^{3}$. Meanwhile pollutants from other chemical compounds in the flue gas are $\mathrm{NO}_{2}=80.7785-83.3725 \mathrm{mg} / \mathrm{m}^{3}$ and $\mathrm{SO}_{2}=10.85-10.98 \mathrm{mg} / \mathrm{m}^{3}$. Pollutants from ambient air are $\mathrm{NO}_{2}=179.11-236.49 \mu \mathrm{g} / \mathrm{Nm}^{3}, \mathrm{SO}_{2}=112.56-256.52 \mu \mathrm{g} / \mathrm{Nm}^{3}$, $\mathrm{CO}=43.80-100.98 \mu \mathrm{g} / \mathrm{Nm}^{3}, \mathrm{HC}=0.05-0.64 \mu \mathrm{g} / \mathrm{Nm}^{3}$, and $\mathrm{O}_{3}=2.8098-19.6065$ $\mu \mathrm{g} / \mathrm{Nm}^{3}$. The total particle's content is also low, which is about $0.283 \mathrm{mg} / \mathrm{m}^{3}$ in the coke baking oven's chimneys, $0.554 \mathrm{mg} / \mathrm{m}^{3}$ in the tungkik kiln's chimneys and $0.259 \mathrm{mg} / \mathrm{m}^{3}$ in the metal melting locations. Comparison of the measurement results with that of quality standard defined by the government regulation of the Republic of Indonesia No.41 Year 1999 about air pollution control, show that the results is far below the tolerated level. Therefore, the existence of coke baking oven is still feasible and safe to the environment.
\end{abstract}

Kata kunci: briket kokas, pencemaran lingkungan, logam berat

\section{PENDAHULUAN}

\subsection{Latar Belakang}

Indonesia yang memiliki cadangan batubara yang cukup banyak, ternyata masih mengimpor kokas untuk bahan bakar pada industri pengecoran logam baik di industri kecil maupun di industri menengah dan besar. Impor kokas ini akan semakin meningkat dengan meningkatnya pertumbuhan industri pengecoran logam di Indonesia.

Pembuatan kokas yang biasa dilakukan di luar negeri adalah dengan cara membakar batubara didalam tungku pembuatan kokas atau
Coke-oven. Cara ini membutuhkan umpan batubara yang bermutu tinggi ditinjau dari jumlah kandungan karbon dan kadar zat-zat volatil serta sifat coking nya (sifat mengkokas). Menurut Ambyo (Mangunwidjaja Ambyo, 1980), batubara Ombilin merupakan batubara dengan jenis terbaik yang ada di Indonesia, namun ternyata mutu kokas yang dihasilkan belum memenuhi syarat untuk pemakaian pada tungku pengecoran logam Hal ini terbukti setelah batubara Ombilin dijadikan kokas dalam tungku jenis sarang tawon (beehive oven). Tungku ini dibuat sejak tahun 1983 di Desa Bukit Gadang Kodya Sawahlunto oleh Pusat Pengembangan Teknologi Mineral 
(PPTM) Bandung, kebetulan penulis sempat ikut dalam percobaan perdananya pada tahun 1984 . Karena kokas yang dihasilkan tungku ini tidak memenuhi persyaratan kokas yang digunakan sebagai bahan bakar pada tungku pengecoran logam, maka kegiatan tersebut dihentikan setelah beroperasi selama lebih kurang 2 tahun.

Sejak tahun 1998 BPPT bekerjasama dengan PPTM Bandung dan Departemen Perindustrian dan Perdagangan, mencoba meningkatkan mutu kokas Ombilin tersebut dengan menggunakan sistem pengkokasan dengan proses karbonisasi dua tingkat. Setelah melalui serangkaian percobaan skala laboratorium, maka pada akhir tahun 1999 dibangun tungku percontohan kokas di Desa Batur Kecamatan Ceper, Kabupaten Klaten, Propinsi Jawa Tengah, dengan kapasitas produksi $500 \mathrm{~kg}$ per hari. Desa Batur ini dipilih karena di sekitar daerah tersebut banyak industri kecil dan menengah pengecoran logam yang membutuhkan dan akan menyerap kokas yang dihasilkan.

Menurut Bambang (Bambang., 1998), untuk bisa menghasilkan kokas yang mendekati persyaratan yang diperlukan untuk pengecoran logam, digunakan cara pembuatan kokas dengan sistem double process. Pada proses ini batubara Ombilin terlebih dahulu dibuat semi kokas pada tungku sarang tawon (beehive), kemudian semikokas tersebut digerus atau grinding serta diayak (disaring) pada ayakan $3 \mathrm{~mm}$. Selanjutnya semikokas halus dicampur dengan aspal sebagai bahan pengikat kemudian dibriket dengan tekanan $250-400 \mathrm{~kg} / \mathrm{cm}^{2}$. Hasil pembriketan ini kemudian dibakar pada suhu diatas $900{ }^{\circ} \mathrm{C}$ di dalam tungku yang disebut dengan tungku karbonisasi suhu tinggi.

Dengan cara ini akan didapat jenis kokas yang memenuhi persyaratan untuk digunakan pada tungku tungkik (tungku untuk melelehkan logam) di industri pengecoran logam rakyat. Namun keberhasilan dari segi mutu kokas yang didapat ternyata menghasilkan masalah baru berupa pencemaran lingkungan.

\subsection{Permasalahan Lingkungan.}

Pencemaran logam berat terhadap lingkungan selain disebabkan oleh panggunaan logam tersebut secara langsung, juga disebabkan oleh oksidasi dan pembentukan garam logam berat sebagai hasil reaksi kimia logam tersebut dengan senyawa lainnya. Dalam proses industri yang memerlukan suhu tinggi seperti pembakaran batubara dan pemurnian minyak bumi atau biasa disebut kilang minyak, maupun pengecoran logam, banyak mengeluarkan limbah yang mencemari lingkungan. Hal ini terutama terjadi pada logam-logam yang relatif mudah menguap dan larut dalam air (berbentuk ion), seperti arsen (As), kadmium (Cd), merkuri ( $\mathrm{Hg})$ dan timah hitam $(\mathrm{Pb})$, serta partikulat yang dapat mencemari udara serta mengganggu kesehatan.

Menurut Endang (Boedoyo M.S dan Endang S., 1996) pembakaran batubara yang menjadi penyebab utama pencemaran lingkungan adalah emisi-emisi $\mathrm{SO}_{x}, \mathrm{NO}_{x}$ dan partikel debu. Ketiga jenis emisi tersebut secara langsung maupun tak langsung menyebabkan kerugian bagi manusia dan lingkungan. Seperti penyebab terjadinya perubahan cuaca, hujan asam, terhambatnya radiasi matahari, terganggunya pertumbuhan tanaman dan terganggunya kesehatan manusia, seperti penyaklit paru-paru dan pernafasan. Biasanya gangguan yang ditimbulkan antara lain iritasi mata, saluran pernafasan, pandangan kabur. Adanya logam berat pada konsentrasi 117 - $205 \mu \mathrm{g} / \mathrm{m}^{3}$ dalam waktu paparan 2 - 3 tahun dapat menyebabkan bronchitis gawat. Pada konsentrasi $162 \mathrm{mg} / \mathrm{m}^{3}$ dalam waktu paparan 30 menit, akan menimbulkan bisul-bisul berair pada paru-paru. Adanya partikel debu akan mengendap di paru-paru dan menimbulkan berbagai gangguan pernafasan. Pada tahun 1991 lebih dari 6\% dari luas pulau Jawa sudah merupakan daerah kritis, diperkirakan pada tahun 2021 daerah kritis tersebut akan berkembang menjadi $38 \%$ dari luas pulau Jawa.

\subsection{Pencemaran Akibat Pembakaran Batubara.}

Batubara merupakan salah satu bahan bakar atau sumber energi dari fosil biologi. Batubara digunakan juga sebagai bahan baku pembuatan kokas untuk pengecoran atau peleburan logam. Dalam pengolahan atau pembakaran batubara menjadi kokas terjadi asap dan gas sebagai limbah yang mencemari lingkungan. Biasanya gas buang pada pembakaran batubara mengandung logam arsen (As), kadmium (Cd), timah hitam $(\mathrm{Pb})$ dan merkuri $(\mathrm{Hg})$.

Kondisi dan tingkat pencemaran dari logam berat yang berasal dari gas buang pada pembakaran batubara sangat tergantung pada

- Daya gabung (afinitas) dari logam yang terdapat dalam batubara ataupun minyak dengan mineral lainnya.

- Sifat-sifat fisik dan kimia serta tinggi rendahnya kandungan logam tersebut dalam bahan bakar

- Kondisi pembakaran (suhu tinggi).

Walaupun logam berat yang berbahaya tersebut kadarnya dalam batubara dan minyak bumi sangat kecil, tetapi kekuatan untuk menyebabkan keracunan terhadap lingkungan 
sangat besar. Logam-logam berat tersebut biasanya terikat dalam bentuk bahan organik dan fraksi mineral. Kandungan logam berat dari gas buang pembakaran batubara dan minyak mentah dapat dilihat pada Tabel 1 dibawah ini.

Tabel 1, Kandungan $\mathrm{As}, \mathrm{Cd}, \mathrm{Pb}$ dan $\mathrm{Hg}$ dalam batubara dan minyak mentah $(\mu \mathrm{g} / \mathrm{g})$

\begin{tabular}{|c|c|c|c|}
\hline No. & Logam & Batubara & $\begin{array}{c}\text { Minyak } \\
\text { mentah }\end{array}$ \\
\hline 1 & $\mathrm{As}$ & $0,34-130$ & $0,0024-1,63$ \\
2 & $\mathrm{Cd}$ & $0,01-300$ & $0,0300-2,10$ \\
3 & $\mathrm{~Pb}$ & $0,70-220$ & $0,0010-0,31$ \\
4 & $\mathrm{Hg}$ & $0,01-1,6$ & $0,014-30$ \\
\hline
\end{tabular}

\subsection{Pencemaran Akibat Pembakaran Aspal}

Aspal merupakan sisa atau buangan (residu) dari pemurnian minyak mentah pada kilang minyak. Dari pemurnian minyak mentah tersebut diperkirakan ada sekitar 30\% kandungan logam berat dalam minyak mentah terdapat dalam aspal tersebut.

Pada penelitian ini aspal yang digunakan sebagai bahan pengikat (binder) adalah aspal dari kilang minyak Dumai, Propinsi Riau. Banyaknya aspal yang digunakan adalah antara $8-10 \%$ bobot bubuk semikokas. Untuk mengetahui pencemaran udara oleh gas, partikel dan logam berat, yang terdapat dalam aspal dilakukan pengamatan pada saat pembakaran briket semikokas yang telah dicampur dengan aspal sebagai bahan perekat.

Setiap minyak mentah akan berbeda kandungan logam beratnya sesuai dengan asal atau sumber minyak mentah tersebut. Sebagai gambaran dapat dilihat pada tabel 2, banyaknya logam berat yang mencemari lingkungan di daratan Eropah akibat pembakaran batubara dan pembakaran minyak di Eropah pada tahun 1979.

Tabel 2. Kandungan logam berat dari limbah penggunaan energi batubara dan minyak di Eropah tahun 1979 (ton/tahun)

\begin{tabular}{|c|c|c|c|c|c|}
\hline \multirow{2}{*}{\multicolumn{2}{|c|}{ Sumber }} & \multicolumn{4}{|c|}{ Logam Berat } \\
\hline & & As & Cd & $\mathbf{P b}$ & $\mathrm{Hg}$ \\
\hline A. & $\begin{array}{l}\text { Pembakaran } \\
\text { Batubara } \\
\text { 1. Energi Listrik } \\
\text { 2. Pabrik } \\
\text { 3. Rumah Tangga } \\
\quad \text { dan Komersial }\end{array}$ & $\begin{array}{r}205 \\
240 \\
16\end{array}$ & $\begin{array}{l}64 \\
77 \\
\\
5\end{array}$ & $\begin{array}{r}733 \\
870 \\
73\end{array}$ & $\begin{array}{c}85,5 \\
- \\
135\end{array}$ \\
\hline & $\begin{array}{l}\text { Pembakaran Minyak } \\
\text { 1. Energi Listrik } \\
\text { 2. Rumah Tangga } \\
\text { dan Komersial }\end{array}$ & $\begin{array}{c}79 \\
138\end{array}$ & $\begin{array}{l}37 \\
73\end{array}$ & $\begin{array}{l}450 \\
709\end{array}$ & $\begin{array}{l}\text { SR } \\
\text { SR }\end{array}$ \\
\hline
\end{tabular}

Keterangan :

Sumber, Pacyna (1987) dalam Darmono (Darmono, 1995)

$(-)$ = tidak tercatat

$\mathrm{SR}=$ Sangat rendah

Mengingat di desa Batur terdapat banyak sentra industri kecil dengan jumlah penduduk nya yang padat, maka upaya pengembangan pembuatan kokas tersebut tidak hanya dengan meningkatkan kualitas dan kuantitas produk saja, tapi juga yang paling penting adalah mengelola limbah atau pencemaran yang ditimbulkannya. Untuk itu perlu dilakukan penelitian gas-gas beracun terutama logam berat yang dihasilkannya serta mengkaji sejauh mana dampaknya terhadap lingkungan udara, baik di sekitar pabrik maupun di sekitar Desa Batur.

\subsection{Tujuan Penelitian.}

Dalam proses pembuatan kokas tersebut, yang meliputi proses-proses pembakaran batubara dan aspal dengan suhu tinggi, maka diperkirakan akan mengeluarkan gas pencemar atau emisi gas beracun berupa gas-gas yang mengandung logam berat yang terdapat dalam umpan batubara dan aspal. Penelitian ini bertujuan untuk melihat pencemaran logam berat yang ditimbulkan oleh industri pembuatan kokas untuk pengecoran logam, pada Proyek Percontohan Pembuatan Kokas di desa Batur Kecamatan Ceper, Kabupaten Klaten. Penelitian ini dilakukan dengan menganalisa partikulat yang terdapat pada gas buang dan kandungan logam berat (As, $\mathrm{Pb}, \mathrm{Cd}, \mathrm{Hg}$ ) yang ditimbulkan selama proses pembakaran semikokas menjadi kokas dan pada saat kokas tersebut digunakan sebagai bahan bakar pada tungku pengecoran logam (tungku tungkik). untuk mengetahui tingkat toksisitasnya. Dari hasil penelitian ini diharapkan akan menghasilkan suatu rekomendasi kepada pemerintah apakah tungku pembuatan kokas maupun tungku tungkik tersebut perlu dilengkapi dengan alat untuk mengurangi pencemaran yang ditimbulkan atau tidak. Bahkan bila perlu ditutup sama sekali apabila tingkat pencemarannya sangat tinggi

\subsection{Manfaat Penelitian.}

Penelitian ini berguna untuk mengetahui sejauh mana dampak pembakaran batubara atau kokas dan aspal terhadap lingkungan. Dengan data yang ada dapat diperkirakan berapa banyak sebuah pabrik boleh berdiri dan beroperasi dalam luasan daerah tertentu, sehingga tidak berdampak negatif terhadap lingkungan alam di sekitarnya. 
Keberadaan tungku percontohan pembuatan kokas di Desa Batur Kecamatan Ceper, Kabupaten Klaten, menyebabkan lingkungan alam tercemar. Akibatnya akan terjadi penurunan kualitas lingkungan dan kesehatan masyarakat disekitarnya.

Dengan berhasilnya percobaan tungku percontohan kokas, maka diharapkan akan berlanjut dengan pembangunan tungku komersial kokas. Hal ini dapat memacu pembangunan industri kecil dan menengah diwilayah tersebut dan peningkatan kesejahteraan masyarakat, sebaliknya akan berdampak pada peningkatan pencemaran lingkungan.

\section{BAHAN DAN METODE}

\subsection{Bahan dan Alat.}

\subsubsection{Bahan}

Bahan yang digunakan pada analisis gas buang tersebut adalah bahan kimia pelengkap pada peralatan analisis, seperti aquabidest serta bahan pendukung lainnya.

\subsubsection{Alat}

Alat yang digunakan meliputi peralatan utama yang disebut dengan Impaktor bertingkat (cascade impactor) bertekanan rendah buatan Andersen USA. Alat ini mempunyai 14 tingkat pengendapan atau penyaringan pada laju alir 28,3 I/menit selama 1-2 jam. Alat ini dilengkapi dengan pompa vakum atau pompa hisap, manometer beda tekanan dan pengukur kecepatan aliran udara, serta timbangan elektronik dengan kepekaan 0,00001 gram dan alat analisis, Spektrometri-Gama atau Spektrometri $(\gamma)$, Atomic Absorbtion Spectrometry (AAS) .

\subsection{Waktu dan Lokasi Penelitian}

Kegiatan penelitian dilakukan selama 6 bulan, yang difokuskan di desa Batur Kecamatan Ceper, Kabupaten Klaten, Propinsi Jawa Tengah. Sementara pada proses pembakaran batubara menjadi semikokas yang dilakukan di Ombilin digunakan sebagai data pendukung.

Contoh udara yang tercemar diambil ditungku pembuatan kokas dan tungku pengecoran logam (tungku tungkik) yang menggunakan kokas tersebut sebagai bahan bakarnya di desa Batur. Pengambilan sampel udara tercemar dilakukan secara acak pada titiktitik di sekitar cerobong, di sekitar tungku dan di sekitar lokasi pada saat kegiatan sedang berlangsung. Analisis laboratorium terhadap contoh udara tercemar dilakukan di Laboratorium
Kimia Pusat Aplikasi Isotop dan Radiasi (PAIRBATAN) Jakarta.

\subsection{Rancangan penelitian}

Jenis data yang dikumpulkan dalam penelitian ini adalah data primer dan data sekunder. Data primer merupakan data yang berkaitan dengan zat-zat kimia pencemar yang mencemari udara seperti kandungan logam berat $\mathrm{Pb}, \mathrm{As}, \mathrm{Cd}, \mathrm{Hg}$, serta debu pada udara di sekitar pabrik.

Data sekunder yang dikumpulkan adalah berupa data yang berkaitan dengan kondisi sekitar pabrik serta suhu, arah, kecepatan angin dan data pendukung lainnya. Dengan menghubungkan antara pencemaran udara dengan kandungan logam berat yang terdapat dalam sampel dan membandingkannya dengan standar pencemaran udara yang diperbolehkan, sesuai dengan UU nomor 23 tahun 1997, tentang Pengelolaan Lingkungan Hidup, dapat diperkirakan sejauh mana pencemaran udara oleh partikel, gas dan logam berat didesa BaturCeper, Klaten telah mengganggu manusia sebagai subjek pembangunan.

\subsection{Metode Penelitian}

Dalam penelitian ini pengamatan pencemaran udara difokuskan pada pencemaran yang disebabkan partikulat dan logam berat yang mungkin ada selama proses pembakaran kokas dan pada saat kokas tersebut digunakan untuk melelehkan logam di tungku tungkik.

Penelitian ini dilakukan dalam beberapa tahap yaitu tahap persiapan, pengambilan sampel dan analisis sampel di laboratorium.

\subsubsection{Tahap Persiapan}

Pada tahap persiapan ini dilakukan pengamatan mulai dari pembuatan semikokas, pembuatan briket semikokas dan pembakaran briket semikokas menjadi kokas serta penggunaan briket kokas tersebut di industri pengecoran logam .

\subsubsection{Pembuatan Semikokas.}

Semikokas sebagai bahan baku briket kokas dibuat dengan cara membakar batubara dengan jumlah udara terbatas dalam suatu tungku yang disebut beehive oven, cara ini biasa juga disebut sebagai proses karbonisasi tingkat pertama. Tungku yang digunakan untuk karbonisasi ini terdapat di Desa Kayu Gadang yang berdekatan dengan tambang batubara Ombilin di Sumatera Barat. Adapun jenis batubara yang digunakan termasuk dalam jenis subbituminous dengan spesifikasi sebagai berikut . 
Tabel 4. Analisis Kualitas Batubara Ombilin

\begin{tabular}{|c|c|c|}
\hline Analisis Proksimat & Basis & $\%$ \\
\hline $\begin{array}{l}\text { Total Moisture (Total Air) } \\
\text { Inherent Moisture } \\
\text { (Air Terikat) } \\
\text { A b u } \\
\text { Zat Terbang } \\
\text { Karbon Padat }\end{array}$ & $\begin{array}{c}\text { ar (as received) } \\
\text { adb (kering-udara) } \\
\text { adb (kering-udara) } \\
\text { adb (kering-udara) } \\
\text { adb (kering-udara) }\end{array}$ & $\begin{array}{c}11.00 \\
7,28 \\
5,32 \\
38,10 \\
49,30\end{array}$ \\
\hline Sulfur & adb (kering-udara) & 0,51 \\
\hline Nilai Kalori & Kalori/gram & 6975 \\
\hline
\end{tabular}

Sumber : Hasil analisis di Lab. PPTM Bandung.

Adapun kapasitas tungku adalah 18 ton untuk sekali pembakaran dengan waktu pembakaran selama lebih kurang 18 jam. Hasil karbonisasi yang biasa disebut dengan semikokas didinginkan secara mendadak dengan cara menyiram dengan air atau quenching. Semikokas yang dihasilkan berbentuk bungkahan berukuran diameter antara $3 \mathrm{~cm}$ sampai dengan $10 \mathrm{~cm}$, selanjutnya dilakukan analisis terhadap kualitas nya di Lab. PPTM Bandung yang meliputi analisis proksimat, kadar sulfur dan nilai kalor dengan hasil sebagai berikut:

Tabel 5. Analisis Kualitas Semi Kokas Ombilin

\begin{tabular}{|c|c|c|}
\hline Sifat Kimia & Basis & $\%$ \\
\hline $\begin{array}{l}\text { Inherent Moisture } \\
\text { (Air Terikat) } \\
\text { Abu } \\
\text { Zat Terbang } \\
\text { Karbon Padat } \\
\text { Sulfur } \\
\text { Nilai Kalori }\end{array}$ & $\begin{array}{c}\text { ar (as received) } \\
\text { adb (kering-udara) } \\
\text { adb (kering-udara) } \\
\text { adb (kering-udara) } \\
\text { adb (kering-udara) } \\
\text { Kalori/gram }\end{array}$ & $\begin{array}{c}3,52 \\
7,14 \\
5,33 \\
84,01 \\
0,58 \\
7177\end{array}$ \\
\hline Sifat Fisik & Satuan & Value \\
\hline $\begin{array}{l}\text { Distribusi Ukuran } \\
\text { (3 inchi) } \\
\text { Kuat Tekan } \\
\text { Shatter Index (2 inchi) }\end{array}$ & $\begin{array}{c}\% \\
\mathrm{~kg} / \mathrm{cm}^{2} \\
\%\end{array}$ & $\begin{array}{l}45 \\
10 \\
55\end{array}$ \\
\hline
\end{tabular}

Sumber: Hasil analisis di Lab. PPTM Bandung.

Kemudian semikokas ini dibawa ke Klaten dan dilakukan proses selanjutnya.

\subsubsection{Pembuatan Briket Semikokas.}

Semikokas yang berbentuk bungkahan tersebut dibawa ke desa Ceper - Klaten kemudian dihaluskan menggunakan alat crusher dan pulverizer serta pengayakan, sehingga dihasilkan bubuk semikokas dengan ukuran -8 mesh dan - 20 mesh artinya bubuk yang lolos ayakan 8 mesh dan yang lolos ayakan 20 mesh kemudian kedua ukuran ini dicampurkan dengan komposisi, -8 mesh sebanyak $60 \%$ dan -20 mesh sebanyak $40 \%$. Selanjutnya semikokas tersebut dicampur dengan dengan aspal yang telah dileleh kan pada suhu sekitar $150{ }^{\circ} \mathrm{C}$ kemudian diaduk sampai homogen dengan alat pengaduk. Kemudian setelah suhu campuran semikokas dengan aspal mendekati $70{ }^{\circ} \mathrm{C}$, dipress atau ditekan dengan mesin pembriketan pada tekanan sekitar $400 \mathrm{~kg} / \mathrm{cm} 2$ dalam cetakan berbentuk silinder, sehingga dihasilkan briket semikokas berukuran diameter $10 \mathrm{~cm}$ dan tinggi $9 \mathrm{~cm}$.. Selanjutnya briket semikokas tersebut didinginkan pada suhu kamar.

\subsubsection{Karbonisasi Suhu Tinggi}

Selanjutnya briket semikokas yang sudah dingin dan mengeras dibakar dalam tungku pengkokasan atau tungku karbonisasi suhu tinggi. Tungku ini berukuran $4 \times 3$ meter dengan kapasitas $500 \mathrm{~kg}$ untuk setiap kali pembakaran. Briket semikokas disusun secara horizontal dalam tabung besi yang terdapat dalam tungku kemudian ditutup ujung pangkalnya. Karbonisasi tahap kedua ini dilakukan dengan menggunakan minyak tanah sebagai bahan bakar pada suhu $800-900{ }^{\circ} \mathrm{C}$, dengan laju pemanasan sekitar $2 \%$ menit. Setelah pemanasan mencapai suhu yang ditentukan dengan lama pemanasan sekitar 10 jam, pembakaran dihentikan dan briket kokas panas yang dihasilkan dikeluarkan dan didinginkan dengan cara menyiram dengan air (quenching). Dalam proses ini akan dihasilkan kokas dengan mutu yang mendekati mutu kokas impor sehingga dapat digunakan untuk melelehkan logam pada tungku tungkik yang terdapat disekitar desa Ceper-Klaten. Kokas yang dihasilkan dilakukan analisis di Lab. PPTM Bandung dengan hasil dapat dilihat pada tabel dibawah ini.

Besarnya partikel asap yang ditimbulkan pada saat kegiatan pembuatan kokas dan pada lokasi pengecoran logam dapat diketahui dengan menimbang berat partikel yang menempel pada setiap saringan yang terdapat dalam impaktor bertingkat sebanyak 13 buah. Ada tiga lokasi yang diukur, yaitu (1) dicerobong tungku pembuatan kokas, (2) diatas tungku pengecoran logam dan (3) dilokasi pengecoran itu sendiri dari hasil rata-rata pengambilan sampel didapat data seperti tabel dibawah ini. 
Tabel 7. Distribusi Diameter Partikel Pada Cerobong Tungku Kokas

\begin{tabular}{|c|c|c|c|c|c|c|}
\hline Tingkat & $\begin{array}{l}\text { Diameter } \\
\text { (mikron) }\end{array}$ & $\mathrm{MO}(\mathrm{gr})$ & M1(gr) & Total (gr) & $\begin{array}{l}\text { Konsentrasi } \\
\text { DM1 (\%) }\end{array}$ & $\%$ Kumulatif \\
\hline 0 & $>35$ & 1.87544 & 1.87544 & 0 & 0.0000 & 100.0000 \\
\hline 1 & 21.70 & 1.92803 & 1.92803 & 0 & 0.0000 & 100.0000 \\
\hline 2 & 15.70 & 2.08934 & 2.08940 & $6 \mathrm{E}-05$ & 12.5000 & 87.5000 \\
\hline 3 & 10.50 & 2.11213 & 2.11223 & $1 \mathrm{E}-05$ & 20.8333 & 66.6667 \\
\hline 4 & 6.60 & 2.08975 & 2.08978 & $3 \mathrm{E}-05$ & 6.2500 & 60.4167 \\
\hline 5 & 3.30 & 2.05025 & 2.05025 & 0 & 0.0000 & 60.4167 \\
\hline 6 & 2.00 & 2.03390 & 2.03391 & $1 \mathrm{E}-05$ & 2.0833 & 58.3333 \\
\hline 7 & 1.40 & 2.04581 & 2.04581 & 0 & 0.0000 & 58.3333 \\
\hline L1 & 0.90 & 2.10243 & 2.10253 & $1 \mathrm{E}-04$ & 20.8333 & 37.5000 \\
\hline L2 & 0.52 & 2.08657 & 2.08660 & $3 \mathrm{E}-05$ & 6.2500 & 31.2500 \\
\hline L3 & 0.23 & 2.07488 & 2.07488 & 0 & 0.0000 & 31.2500 \\
\hline L4 & 0.11 & 2.08945 & 2.08949 & $4 \mathrm{E}-05$ & 8.3333 & 22.9167 \\
\hline L5 & 0.08 & 2.08183 & 2.08188 & $5 \mathrm{E}-05$ & 10.4167 & 12.5000 \\
\hline FILTER & $<0.08$ & 0.32804 & 0.32810 & $6 \mathrm{E}-05$ & 12.5000 & 0.0000 \\
\hline \multicolumn{4}{|c|}{ Jumlah } & 0.00048 & 100.00000 & \\
\hline
\end{tabular}

Tabel 8. Distribusi Diameter Partikel Pada Cerobong Tungku Tungkik.

\begin{tabular}{|c|c|c|c|c|c|c|}
\hline Tingkat & $\begin{array}{c}\text { Diameter } \\
\text { (mikron) }\end{array}$ & $\mathrm{MO}(\mathrm{gr})$ & M1(gr) & Total $(\mathrm{gr})$ & $\begin{array}{c}\text { Konsentrasi } \\
\text { DM1 (\%) }\end{array}$ & $\begin{array}{c}\% \\
\text { Kumulatif }\end{array}$ \\
\hline 0 & $>35$ & 1.88871 & 1.88880 & 9E-05 & 9.5745 & 90.4255 \\
\hline 1 & 21.70 & 1.87496 & 1.87508 & $1 \mathrm{E}-05$ & 2.2727 & 77.6596 \\
\hline 2 & 15.70 & 2.03438 & 2.03444 & $6 \mathrm{E}-05$ & 6.3830 & 71.2766 \\
\hline 3 & 10.50 & 2.01202 & 2.01210 & $8 \mathrm{E}-05$ & 8.5106 & 62.7660 \\
\hline 4 & 6.60 & 2.03167 & 2.03171 & 4E-05 & 4.2553 & 58.5106 \\
\hline 5 & 3.30 & 2.02421 & 2.02424 & 3E-05 & 3.1915 & 55.3191 \\
\hline 6 & 2.00 & 2.09269 & 2.09270 & 1E-05 & 1.0638 & 54.2553 \\
\hline 7 & 1.40 & 2.11608 & 2.11628 & 0.0002 & 21.2766 & 32.9787 \\
\hline L1 & 0.90 & 2.12319 & 2.12322 & $3 E-05$ & 3.1915 & 297872 \\
\hline L2 & 0.52 & 2.01637 & 2.01641 & $4 \mathrm{E}-05$ & 4.2553 & 25.53 .19 \\
\hline L3 & 0.23 & 2.02613 & 2.02613 & 0 & 0.0000 & 25.5319 \\
\hline L4 & 0.11 & 2.01274 & 2.01289 & 0.00015 & 15.9574 & 9.5745 \\
\hline L5 & 0.08 & 2.12261 & 2.12268 & 7E-05 & 7.4468 & 2.1277 \\
\hline FILTER & $<0.08$ & 0.32963 & 0.32965 & 2E-05 & 2.1277 & 0.0000 \\
\hline \multicolumn{4}{|c|}{ Jumlah } & 0.00094 & 100.00000 & \\
\hline
\end{tabular}

Tabel 9. Distribusi Diameter Partikel Pada Lokasi Pengecoran Baja.

\begin{tabular}{|c|c|c|c|c|c|c|}
\hline Tingkat & $\begin{array}{c}\begin{array}{c}\text { Diameter } \\
\text { (mikron) }\end{array} \\
\end{array}$ & M0 (gr) & M1(gr) & Total (gr) & \begin{tabular}{|c|} 
Konsentrasi \\
DM1 (\%)
\end{tabular} & $\begin{array}{c}\% \\
\text { Kumulatif }\end{array}$ \\
\hline 0 & $>35$ & 1.88431 & 1.88436 & $5 \mathrm{E}-05$ & 11.3636 & 88.6364 \\
\hline 1 & 21.70 & 1.90216 & 1.90217 & $1 \mathrm{E}-05$ & 2.2727 & 86.3636 \\
\hline 2 & 15.70 & 2.08654 & 2.08655 & $1 \mathrm{E}-05$ & 2.2727 & 84.0909 \\
\hline 3 & 10.50 & 2.09230 & 2.09233 & $3 E-05$ & 6.8182 & 77.2727 \\
\hline 4 & 6.60 & 2.08225 & 2.08228 & $3 \mathrm{E}-05$ & 6.8182 & 70.4545 \\
\hline 5 & 3.30 & 2.09668 & 2.09669 & $1 \mathrm{E}-05$ & 2.2727 & 68.1818 \\
\hline 6 & 2.00 & 2.03920 & 2.03920 & 0 & 0.0000 & 68.1818 \\
\hline 7 & 1.40 & 2.04365 & 2.04366 & $1 \mathrm{E}-05$ & 2.2727 & 65.9091 \\
\hline L1 & 0.90 & 2.02890 & 2.02899 & $9 \mathrm{E}-05$ & 20.4545 & 45.4545 \\
\hline L2 & 0.52 & 2.07572 & 2.07572 & 0 & 0.0000 & 45.4545 \\
\hline L3 & 0.23 & 2.04079 & 2.04079 & 0 & 0.0000 & 45.4545 \\
\hline L4 & 0.11 & 1.75847 & 1.75852 & $5 \mathrm{E}-05$ & 11.3636 & 34.0909 \\
\hline L5 & 0.08 & 2.09652 & 2.09653 & $1 \mathrm{E}-05$ & 2.2727 & 31.8182 \\
\hline FILTER & $<0.08$ & 0.33089 & 0.33103 & 0.00014 & 31.8182 & 0.0000 \\
\hline \multicolumn{4}{|c|}{ Jumlah } & 0.00044 & 100.00000 & \\
\hline
\end{tabular}

\subsubsection{Tahap Analisis}

Sampel gas dan partikel pencemar yang dikumpulkan dianalisa kandungan logam berat seperti $\mathrm{Hg}, \mathrm{Cd}$, dan As dengan menggunakan alat spektrometri- $\gamma$. Kadar dan ukuran partikel gas dapat ditentukan dari penimbangan partikel yang menempel pada tiap piringan saringan yang terdapat dalam alat impactor bertingkat.

\section{HASIL DAN PEMBAHASAN}

\subsection{Hasil Pengukuran Partikel Asap}

Pengambilan sampel dilakukan selama 1 Jam dengan kecepatan aliran udara 28,3 liter/menit, untuk tiap sampel. Maka banyaknya udara yang diambil setiap jam adalah 28,3 liter x $60=1.698$ liter/jam $=1,698 \mathrm{~m}^{3} / \mathrm{jam}$. Partikel total yang keluar dari cerobong tungku kokas adalah $0,00048 \times 1000 / 1,698 \mathrm{~m}^{3}=0,283 \mathrm{mg} / \mathrm{m}^{3}$, partikel total yang keluar dari tungku tungkik adalah $0,00094 \times 1000 / 1,698 \mathrm{~m}^{3}=0,554 \mathrm{mg} / \mathrm{m}^{3}$, partikel total yang terdapat disekitar pengecoran adalah $0,00044 \times 1000 / 1,698 \mathrm{~m}^{3}=0,259 \mathrm{mg} /$ $\mathrm{m}^{3}$.

Dari banyaknya partikel total yang dikeluarkan disetiap lokasi, ternyata yang paling rendah adalah dilokasi pengecoran, sedangkan partikel total terbanyak dikeluarkan dilokasi tungku tungkik. Ternyata partikel total yang dikeluarkan pada cerobong tungku kokas masih cukup rendah dibandingkan dengan yang dikeluarkan di cerobong tungku tungkik. Tetapi bila dibandingkan dengan baku mutu emisi gas buang, bahwa total partikel yang dibolehkan adalah $150 \mathrm{mg} / \mathrm{m}^{3}$, maka ternyata total partikel 
yang keluar dari cerobong tungku kokas dan cerobong tungku tungkik masih sangat rendah dan aman terhadap lingkungan (Bapedal, 1999).

Untuk pembahasan banyaknya partikel yang mencemari lingkungan dibagi dalam 3 kelompok ukuran partikel yaitu partikel halus dari $0-2 \mu, 2-$ $10 \mu$ dan $10-35 \mu$, seperti tabel 10 , dibawah ini.

Tabel 10. Persentase Ukuran Partikel Ditiap Lokasi.

\begin{tabular}{|l|c|c|c|}
\hline Lokasi Ukuran Partikel & $0-2 \mu$ & $2-10 \mu$ & $10-35 \mu$ \\
\hline Tungku Kokas (\%) & & & \\
\hline Tungku Tungkik (\%) & 58,33 & 8,33 & 33,34 \\
\hline Lokasi Pengcoran (\%) & 68,18 & 8,52 & 37,23 \\
\hline
\end{tabular}

Dari grafik dibawah ini dapat dilihat distribusi ukuran partikel dan persentase nya disetiap sumber pencemaran. Bila dibandingkan antara banyaknya partikel yang keluar dari tungku kokas dengan tungku tungkik, ternyata ditungku tungkik lebih banyak mengeluarkan partikel kasar $(>10)$ yaitu sebesar $37,23 \%$, hal ini berarti pencemaran dengan partikel berukuran diatas 10 $\mu$ akan lebih banyak terjadi di tungku tungkik. Tetapi partikel halus $0-2 \mu$ lebih banyak dikeluarkan dari tungku kokas, sedangkan partikel berukuran 2 - $10 \mu$ jumlahnya persentasenya hampir sama yaitu sekira $8 \%$.

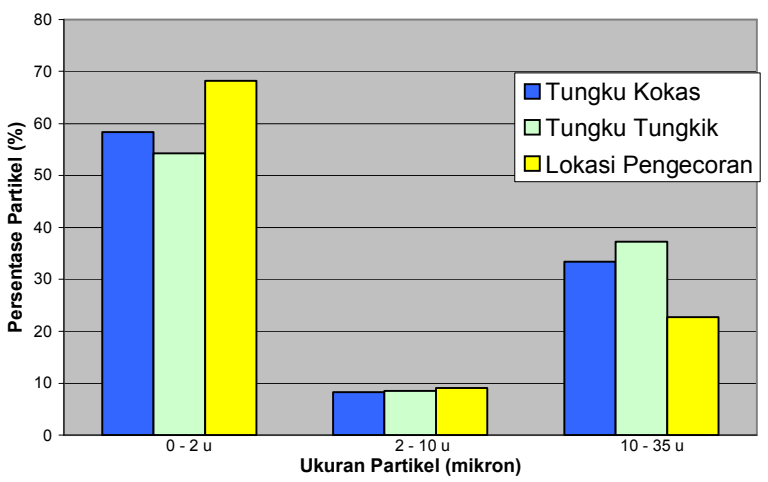

Gambar 2. Grafik Distribusi Ukuran Partikel

\subsection{Hasil Pengukuran logam-logam yang mencemari lingkungan.}

Pengukuran logam maupun kogam berat terhadap gas buang yang yang timbul dilakukan dengan cara menganalisis sampel yang didapat dari impactor bertingkat. Sampel terlebih dahulu diiradiasi dengan menggunakan suatu sumber neutron. Inti atom unsur-unsur yang berada dalam sampel tersebut akan menangkap neutron dan berubah menjadi radioaktif. Setelah paparan radiasi netron dianggap cukup, sampel dikeluarkan dari sumber neutron. Sampel tersebut sekarang mengandung unsur-unsur yang memancarkan sinar-sinar radioaktif. Sinar $\gamma$ atau sinar gama yang dipancarkan oleh berbagai unsur dalam contoh dapat dianalisis secara spektrometri- $\gamma$. Analisis kualitatif setiap unsur dilakukan berdasarkan pengukuran energi sinar$\gamma$, sedangkan analisis kuantitatif dilakukan dengan mengukur intensitasnya. Pada tabel 11, dibawah ini dapat dilihat jenis logam-logam yang terdeteksi berikut kadarnya dalam sampel gas buang yang terjadi selama proses pembuatan kokas dan selama pemakaian kokas tersebut di pengecoran logam.

Tabel 11. Konsentrasi logam yang terdapat dalam gas buang $\left(\mu \mathrm{g} / \mathrm{m}^{3}\right)$.

\begin{tabular}{|c|l|c|c|c|c|c|}
\hline No. & \multicolumn{1}{|c|}{ Lokasi } & $\mathrm{Na}$ & $\mathrm{Al}$ & $\mathrm{Ca}$ & $\mathrm{Fe}$ & $\mathrm{K}$ \\
\hline 1 & Cerobong tungku kokas & 180 & 250 & 897 & 718 & --- \\
2 & Disekitar tungku kokas & 160 & 215 & 935 & 675 & -- \\
3 & Cerobong tungku tungkik & 315 & 360 & 1330 & 2300 & 0,25 \\
4 & Lokasi pengecoran & 250 & 286 & 1260 & 1200 & 0,12 \\
5 & Lingkungan disekitar desa & 100 & 270 & 786 & 478 & 0,05 \\
\hline
\end{tabular}

Keterangan : --- = tidak terdeteksi

Dari tabel diatas terlihat bahwa yang termasuk logam berat hanyalah Fe tetapi masih termasuk logam essensil dalam konsentrasi rendah masih dibutuhkan oleh tubuh dan tanaman. Sedangkan Al walaupun tidak termasuk logam berat tetapi cukup berbahaya karena apabila kelebihan dapat menyebabkan penurunan daya absorpsi tanaman terhadap mineral $\mathrm{Ca}, \mathrm{Mg}$ dan $\mathrm{P}$. Walaupun begitu jumlah logam-logam didalam tabel tersebut masih dibawah ambang batas dan cukup aman bagi lingkungan. Sedangkan logam berat barbahaya lainnya seperti $\mathrm{Hg}, \mathrm{Pb}, \mathrm{Cd}$ dan As tidak terdeteksi sama sekali. Hal ini kemungkinan besar disebabkan karena bahan yang digunakan untuk briket kokas tersebut adalah semikokas, bukan batubara mentah. Karena sewaktu batubara dibakar menjadi semikokas, semua bahan-bahan mudah menguap atau zat terbang yang didalam nya terkandung berbagai macam bahan kimia sudah menguap dan terbakar. Hal ini dapat dilihat pada komposisi kimia semikokas tabel 7, terlihat bahwa kadar zat terbang nya menjadi 5,33 \% dibandingkan dengan batubara sebelum dibakar menjadi semikokas kadar zat terbangnya adalah sebesar $38,10 \%$ pada table 4.

\section{KESIMPULAN DAN SARAN}

Secara umum pencemaran yang terjadi baik dilokasi pabrik kokas maupun dilokasi tungku tungkik pengecoran logam, masih cukup rendah sehingga keberadaan tungku kokas dan pemakaian kokas dalam negeri di idustri pengecoran logam untuk saat ini cukup aman terhadap lingkungan. Walupun kapasitas pabrik 
dinaikkan sampai 2-3 kali lipat yaitu dari $500 \mathrm{~kg}$ kokas perhari menjadi 1-2 ton kokas perhari diperkirakan masih cukup aman terhadap lingkungan. Tetapi hal ini tidak menutup kemungkinan untuk menganalisis ulang kegiatan pabrik kokas tersebut apabila aktifitas pembuatan kokas dan pengecoran logamnya semakin meningkat Disarankan untuk keselamatan pekerja didalam ruang pengcoran perlu dilengkapi dengan alat sirkulasi udara yang baik.

\section{DAFTAR PUSTAKA}

Bambang S R. 1998. 'Pengaruh Proses Karbonisasi Dua-Tingkat Terhadap Kualitas Briket Kokas Ombilin Untuk Industri Pengecoran', Majalah BPPT, Ed. No.LXXXVII/Juli, 72 - 83.
Badan Pengendalian Dampak Lingkungan (BAPEDAL). 1999. Peraturan Pemerintah Republik Indonesia No. 41 Tahun 1999, Tentang Pengendalian Pencemaran Udara.

Boedoyo M.S dan Endang S. 1996. Strategi Penyediaan Energi dan Pencemaran Udara. Seminar Pengembangan Indeks dan Indikator Mutu Lingkungan Udara. 30 Oktober 1996. $\mathrm{KLH}$. Jakarta.

Darmono. 1995. Logam Dalam Sistem Biologi Makhluk Hidup. Penerbit UI Jakarta.

Mangunwidjaja Ambyo, 1980. "Coal Classification and Its Implementation in Indonesia". Prosiding Seminar on Coal Technology and The Indonesian Needs. Jakarta. 